University of Nebraska - Lincoln

DigitalCommons@University of Nebraska - Lincoln

Publications from USDA-ARS / UNL Faculty

U.S. Department of Agriculture: Agricultural

Research Service, Lincoln, Nebraska

2007

\title{
Proteomic and genetic analysis of glycinin subunits of sixteen soybean genotypes
}

\author{
Savithiry Natarajan \\ United States Department of Agriculture-Agricultural Research Service, natarajs@ba.ars.usda.gov \\ Chenping $\mathrm{Xu}$ \\ University of Maryland - College Park \\ Hanhong Bae \\ United States Department of Agriculture \\ Bryan A. Bailey \\ United States Department of Agriculture \\ Perry Cregan \\ United States Department of Agriculture \\ See next page for additional authors
}

Follow this and additional works at: https://digitalcommons.unl.edu/usdaarsfacpub

Part of the Agricultural Science Commons

Natarajan, Savithiry; Xu, Chenping; Bae, Hanhong; Bailey, Bryan A.; Cregan, Perry; Caperna, Thomas J.;

Garrett, Wesley M.; and Luthria, Devanand, "Proteomic and genetic analysis of glycinin subunits of sixteen soybean genotypes" (2007). Publications from USDA-ARS / UNL Faculty. 697.

https://digitalcommons.unl.edu/usdaarsfacpub/697

This Article is brought to you for free and open access by the U.S. Department of Agriculture: Agricultural Research Service, Lincoln, Nebraska at DigitalCommons@University of Nebraska - Lincoln. It has been accepted for inclusion in Publications from USDA-ARS / UNL Faculty by an authorized administrator of DigitalCommons@University of Nebraska - Lincoln. 


\section{Authors}

Savithiry Natarajan, Chenping Xu, Hanhong Bae, Bryan A. Bailey, Perry Cregan, Thomas J. Caperna, Wesley M. Garrett, and Devanand Luthria 


\title{
Proteomic and genetic analysis of glycinin subunits of sixteen soybean genotypes ${ }^{\text {th }}$
}

\author{
Savithiry Natarajan ${ }^{\mathrm{a}, *}$, Chenping Xu ${ }^{\mathrm{b}}$, Hanhong Bae ${ }^{\mathrm{c}}$, Bryan A. Bailey ${ }^{\mathrm{c}}$, Perry Cregan ${ }^{\mathrm{a}}$, \\ Thomas J. Caperna ${ }^{d}$, Wesley M. Garrett ${ }^{e}$, Devanand Luthria ${ }^{\mathrm{f}}$ \\ ${ }^{a}$ US Department of Agriculture, Agricultural Research Service, Soybean Genomics and Improvement Laboratory, PSI, 10300, \\ Baltimore Avenue, Beltsville, MD 20705, USA \\ ${ }^{\mathrm{b}}$ University of Maryland, Department of Plant Science and Landscape Architecture, College Park, MD 20742, USA \\ ${ }^{\mathrm{c}}$ US Department of Agriculture, Agricultural Research Service, Sustainable Perennial Crops Laboratory, Beltsville, MD 20705, USA \\ ${ }^{\mathrm{d}}$ US Department of Agriculture, Agricultural Research Service, Growth Biology Laboratory, Beltsville, MD 20705, USA \\ ${ }^{\mathrm{e}}$ US Department of Agriculture, Agricultural Research Service, Biotechnology and Germplasm Laboratory, Beltsville, MD 20705, USA \\ ${ }^{\mathrm{f}}$ US Department of Agriculture, Agricultural Research Service, Food Composition Laboratory, Beltsville, MD 20705, USA
}

Received 30 October 2006; accepted 30 March 2007

Available online 6 April 2007

\begin{abstract}
We investigated proteomic and genomic profiles of glycinin, a family of major storage proteins in 16 different soybean genotypes consisting of four groups including wild soybean (Glycine soja), unimproved cultivated soybean landraces from Asia (G. max), ancestors of N. American soybean (G. max), and modern soybean (G. max) genotypes. We observed considerable variation in all five glycinin subunits, G1, G2 G3, G4 and G5 using proteomics and genetic analysis. Two-dimensional polyacrylamide gel electrophoresis (2D-PAGE) and mass spectrometry (MS) analysis showed that the wild genotypes had a range of 25-29 glycinin protein spots that included both acidic and basic polypeptides followed by the ancestors with 24-28, modern cultivars with 24-25, and landraces with 17-23 protein spots. Overall, the wild genotypes have a higher number of protein spots when compared to the other three genotypes. Major variation was observed in acidic polypeptides of G3, G4 and G5 compared to $\mathrm{G} 1$ and $\mathrm{G} 2$, and minor variation was observed in basic polypeptides of all subunits. Our data indicated that there are major variations of glycinin subunits between wild and cultivated genotypes rather than within the same groups. Based on Southern blot DNA analysis, we observed genetic polymorphisms in group I genes (G1, G2, and G3) between and within the four genotype groups, but not in group II genes (G4 and G5). This is the first study reporting the comparative analysis of glycinin in a diverse set of soybean genotypes using combined proteomic and genetic analysis.
\end{abstract}

(C) 2007 Elsevier Masson SAS. All rights reserved.

Keywords: Soybean; G. soja; G. max; 2D-PAGE; MALDI-TOF-MS; LC-MS/MS; Glycinin

\section{Introduction}

Soybean glycinin is one of the major seed storage proteins, which accounts for $40 \%$ of the total proteins and is

\footnotetext{
is Mention of trade name, proprietary product or vendor does not constitute a guarantee or warranty of the product by the US Department of Agriculture or imply its approval to the exclusion of other products or vendors that also may be suitable.

* Corresponding author. Tel.: +1 301504 5258; fax: +1 3015045728.

E-mail address: natarajs@ba.ars.usda.gov (S. Natarajan).
}

involved with structural properties of soybean products. Glycinin is responsible for the gel matrix structure related to hardness and unfracturability of tofu [36,38]. The gel formed by glycinin is a turbid gel in contrast to the transparent gel formed by $\beta$-conglycinin. Glycinin has five non-allelic genes, Gy1, Gy2, Gy3, Gy4 and Gy5, which code for five glycinin protein precursor molecules, G1, G2, G3, G4 and G5, respectively [25,28]. Each protein precursor subunit consists of two or three chains, which are cleaved post-translationally [6]. Based on the homology in amino acid sequences, these 
five subunits are classified into two major groups: group I consists of $\mathrm{G} 1$ (A1aBx) G2 (A2B1a), and G3 (A1aB1b) genes and group II contains G4 (A5A4B3) and G5 (A3B4) gene products $[4,38]$. Each subunit consists of acidic (A) and basic (B) polypeptide components [25,32]. The subunit pairings of glycinin molecules are a heterogeneous complex of $\mathrm{A} 1 \mathrm{aBx}, \mathrm{A} 1 \mathrm{aB} 1 \mathrm{~b}, \mathrm{~A} 2 \mathrm{~B} 1 \mathrm{a}, \mathrm{A} 3 \mathrm{~B} 4$ and $\mathrm{A} 5 \mathrm{~A} 4 \mathrm{~B} 3$, which are covalently linked by disulfide bonds except for the A4 subunit present in the G4 subunit $[19,33]$. For each subunit there is more than $84 \%$ homology within the group and $45-49 \%$ between groups [27].

Various subunits of glycinin are considered to play different important roles in tofu gel formation [29]. The presence of more G4 subunit is closely related to gel formation rate and transparency, whereas the presence of more G5 is related to gel hardness [7]. In addition, glycinin is an important storage protein that lowers cholesterol levels in human serum [14]. There are numerous reports on molecular characterization of soybean seeds at the protein and DNA levels that are important for assessing genetic diversity of different genotypes [3]. DNA sequence analysis of wild and cultivated soybean indicates a more than twofold higher sequence diversity in wild versus cultivated soybean [11].

In the past 30 years, many soybean varieties have been developed for adaptation to different geographical regions via plant breeding for increasing productivity and quality. Protein compositions and profiles can be affected by breeding and environmental conditions [2,5]. However, the effects of breeding under different environmental conditions on the composition of storage proteins, such as glycinin, and the associated genetic diversity have not been studied. Furthermore, comparative proteomic and genomic studies of glycinin subunits would aid in the understanding of evolutionary relationships between these genotypes. Therefore, we conducted studies and compared the glycinin protein profiles of a wide range of soybeans using two-dimensional polyacrylamide gel electrophoresis (2D-PAGE) and integrated matrix-assisted laser desorption/ionization time of flight (MALDI-TOF-MS), and liquid chromatography mass spectrometry (LC/MS/MS). In this study, 16 genotypes of soybean including wild and cultivated genotypes were selected to study seed protein variation. The 16 genotypes were selected from four groups including wild soybean (PI366120, PI393551, PI407027, and PI407282), unimproved Asian landraces referred to as landraces (PI423954, PI89138, PI594777 and PI59845), genotypes that are the ancestors of modern North American cultivars referred as to as ancestors (PI548298, PI548445, PI548318 and PI548362), and elite North American genotypes referred to as modern which were released between 1975 and 1990 (PI533655, PI525453, PI513382 and PI536635). In this study, the variation in glycinin protein subunit level was investigated using 2D-PAGE and MS analysis. The wild soybean is completely cross compatible with cultivated soybean, and any variability present in the wild soybean can be moved into soybean cultivars by conventional plant breeding.

\section{Materials and methods}

\subsection{Plant materials}

Soybean seeds of wild (PI407027, PI407282, PI366120, and PI393551), landrace (PI423954, PI89138, PI594777 and PI59845), ancestral (PI548298, PI548445, PI548318 and PI548362), and modern genotypes (PI533655, PI525453, PI513382 and PI536635) were obtained from the USDA soybean germplasm collection, Urbana, IL. The cultivar names for landrace, ancestral and modern genotypes are listed in Table 1.

\subsection{Chemicals}

Chemicals for electrophoresis including acrylamide, bisacrylamide, SDS, TEMED, ammonium persulfate, thiourea, dithiothreitol, CHAPS and IPG strips were purchased from GE Healthcare (Piscataway, NJ). Urea and ampholytes $(\mathrm{pH}$ 3-10, 4.0-7.0 and 6.0-11.0) were purchased from BioRad Laboratories (Hercules, CA). Tris- $\mathrm{HCl}$ (pH 8.8), 2-mercaptoethanol (2-ME), trichloroacetic acid (TCA) and glycerol were purchased from Sigma-Aldrich Chemical Co. (St. Louis, $\mathrm{MO}$ ). Alpha-Cyanohydroxycinnamic acid (CHCA) matrix was purchased from Bruker Daltonics, Billerica, MA. Water from a Millipore Milli-RO4 reverse osmosis system was used for making all solutions.

\subsection{Extraction of proteins from soybeans}

Modified trichloroacetic acid (TCA)/acetone precipitation/ urea solubilization extraction buffer was used to extract seed proteins [23]. For this method, soybean seeds were powdered in liquid nitrogen using a mortar and pestle. One hundred milligrams of soybean seed powder was homogenized with $5 \mathrm{ml}$ of a solution containing $10 \%(\mathrm{w} / \mathrm{v})$ TCA in acetone with $0.07 \%(\mathrm{v} / \mathrm{v}) 2$-mercaptoethanol. Total protein was precipitated for $1 \mathrm{~h}$ or overnight at $-20^{\circ} \mathrm{C}$. The extract was centrifuged at $20,800 \times g$ for $20 \mathrm{~min}$ at $4{ }^{\circ} \mathrm{C}$. The pellet was washed $2-3$ times with acetone containing $0.07 \%$ (v/v) 2-mercaptoethanol. Then the pellet was dried under vacuum for $30 \mathrm{~min}$ and the acetone dry powder was resuspended in $1 \mathrm{ml}$ of lysis buffer $(9 \mathrm{M}$ urea, $1 \%$ CHAPS, $1 \%(\mathrm{w} / \mathrm{v})$ ampholytes $(\mathrm{pH} \mathrm{3-10)}$ and $1 \%$ DTT) followed by sonication on ice for $30 \mathrm{~min}$. Insoluble material was removed by centrifugation at $20,800 \times g$ for $20 \mathrm{~min}$ at $4{ }^{\circ} \mathrm{C}$ and the supernatant was used in 2D-PAGE analysis. The concentration of proteins extracted by the modified TCA/acetone method was determined by the Bradford method [1] using a commercial dye reagent (BioRad).

\subsection{D-PAGE analysis}

The first dimension IEF (100 $\mu \mathrm{g}$ protein) was performed using $13 \mathrm{~cm} \mathrm{pH} 4.0-7.0$ and 6.0-11.0 linear IPG strips in a IPGphor apparatus (GE Healthcare, Piscataway, NJ). A protein molecular weight standard was used for the second dimension in each gel. For the second dimension, the IPG strips were 
Table 1

List of 16 soybean genotypes tested for protein variation

\begin{tabular}{|c|c|c|c|c|c|}
\hline No. & Soybean genotypes & Cultivar & Maturity group & Strain designation & $\begin{array}{l}\text { Origin province } \\
\text { or state/country }\end{array}$ \\
\hline 1 & Ancestor & A.K (Harrow) & III & PI 548298 & China \\
\hline 2 & Ancestor & CNS & VII & PI 548445 & Jiangsu (China) \\
\hline 3 & Ancestor & Dunfield & III & PI 548318 & Jilin (China) \\
\hline 4 & Ancestor & Lincoln & III & PI 548362 & China \\
\hline 5 & Modern & Burlison & II & PI 533655 & Illinois (USA) \\
\hline 6 & Modern & Conrad & II & PI 525453 & Iowa (USA) \\
\hline 7 & Modern & Glenwood & $\mathrm{O}$ & PI 513382 & Minnesota (USA) \\
\hline 8 & Modern & Sprite & III & PI 536635 & Ohio (USA) \\
\hline 9 & Wild & $\mathrm{n} / \mathrm{a}$ & IV & PI 366120 & Akita (Japan) \\
\hline 10 & Wild & $\mathrm{n} / \mathrm{a}$ & $X$ & PI 393551 & Taiwan (Taiwan) \\
\hline 11 & Wild & $\mathrm{n} / \mathrm{a}$ & $\mathrm{V}$ & PI 407027 & Akita (Japan) \\
\hline 12 & Wild & $\mathrm{n} / \mathrm{a}$ & VI & PI 407282 & Cheju (Korea, South) \\
\hline 13 & Landrace & Shirome & $\mathrm{O}$ & PI 423954 & Kumamota (Japan) \\
\hline 14 & Landrace & Zontanorukon & II & PI 89138 & Hamgyong Puk (Korea, North) \\
\hline 15 & Landrace & Liu yue huang & IV & PI 594777 & Yunnan (China) \\
\hline 16 & Landrace & Sohgetsu & $\mathrm{V}$ & PI 59845 & Japan \\
\hline
\end{tabular}

incubated with $50 \mathrm{mM}$ Tris- $\mathrm{HCl} \mathrm{pH} 8.8,6 \mathrm{M}$ urea, $30 \%$ glycerol, $2 \%$ SDS, $0.002 \%$ bromophenol blue, and $1 \%$ DTT for 15 min, acetylated with iodoacetamide and subsequently placed onto $12 \%$ polyacrylamide gels prepared as described by Laemmli [16]. The electrophoresis was performed using a Hoefer SE 600 Ruby electrophoresis unit (GE Healthcare, Piscataway, NJ) according to the manufacturer's recommendations. The 2D-PAGE gels were visualized by staining with colloidal Coomassie Blue G-250 as described by Newsholme et al. [24]. The gels were stored in $20 \%$ ammonium sulfate solution and scanned using laser densitometry (GE Healthcare, Piscataway, NJ). Triplicate samples were used for soybean seed protein extraction and 2D-PAGE analysis.

\subsection{In-gel digestion of protein spots}

Protein spots were excised from the stained gel and washed first with distilled water to remove ammonium sulfate and then with $50 \%$ acetonitrile containing $25 \mathrm{mM}$ ammonium bicarbonate to destain the gel plug. The gel plug was dehydrated with $100 \%$ acetonitrile, dried under vacuum, and then re-swollen with $20 \mu \mathrm{l}$ of $10 \mu \mathrm{g} / \mathrm{ml}$ trypsin (modified porcine trypsin, sequencing grade, Promega, Madison, WI) in $25 \mathrm{mM}$ ammonium bicarbonate. Digestion was performed overnight at $37^{\circ} \mathrm{C}$. The resulting tryptic fragments were extracted with $50 \%$ acetonitrile and 5\% trifluoroacetic acid with sonication. The extract was dried to completeness and dissolved in 50\% acetonitrile and $0.1 \%$ trifluoroacetic acid.

\subsection{Protein identification}

A Voyager DE-STR MALDI-TOF mass spectrometer (Applied Biosystems, Framingham, MA) operated in positive ion reflector mode was used to analyze tryptic peptides. A Thermo Finnigan LCQ Deca XP plus Ion Trap mass spectrometer was used to analyze proteins that were not positively identified by MALDI-TOF mass spectrometry. Protein identification was performed by searching the NCBI non-redundant protein sequence database using the Mascot search engine (http:// www.matrixscience.com/). For MALDI data to qualify as a positive identification, a protein's score had to equal or exceed the minimum significant score. For positive identification of MS/MS spectra, a minimum of two matched peptides were required with at least one peptide having a significant ion score.

\subsection{DNA blot analyses}

Total genomic DNA was isolated from the leaf tissues of 16 different soybean genotypes (Table 1) using DNeasy Plant Mini Kit (Qiagen, Valencia, CA). The integrity of DNA was evaluated by agarose gel electrophoresis. PCR primers were designed based on the sequence of the glycinin A5A4B3 (accession no. AB004062) and the PCR products were used as a probe: forward primer 5 '-CCA TGT TCT CCT CAC TTG TTA- $3^{\prime}$; reverse primer $5^{\prime}$-TTC TCA AGA TAG ACT AAT TG- $3^{\prime}$. The expected size of the PCR product was $907 \mathrm{bp}$. The probe covered the third exon of glycinin A5A4B3 gene (Fig. 1A,B), which contains the hypervariable region of group II genes of glycinin subunits [25]. The following PCR condition was applied: initial activation of Taq DNA polymerase at $94{ }^{\circ} \mathrm{C}$ for $5 \mathrm{~min}$, denaturation for $30 \mathrm{~s}$ at $94{ }^{\circ} \mathrm{C}$, annealing for $30 \mathrm{~s}$ at $55^{\circ} \mathrm{C}$, extension for $1 \mathrm{~min}$ at $72^{\circ} \mathrm{C}$, and an additional 10 min extension at $72{ }^{\circ} \mathrm{C}$, with 30 cycles. The PCR product from each reaction was electrophoresed, purified using QIAEX II Gel Extraction System (Qiagen, Valencia, CA), and cloned into pCR2.1-TOPO vector (Invitrogen, Calsbad, CA) for sequencing to confirm their identity.

A sample of DNA $(2.5 \mu \mathrm{g}$, was digested with HaeIII at $37{ }^{\circ} \mathrm{C}$ overnight, separated in a $0.8 \%$ agarose gel, blotted onto a membrane, and hybridized with the ${ }^{32} \mathrm{P}$-labeled, 907bp fragment. Probe hybridization and blot washing was performed using medium stringency conditions according to Keates et al. [12]. The image was analyzed using a Typhoon 


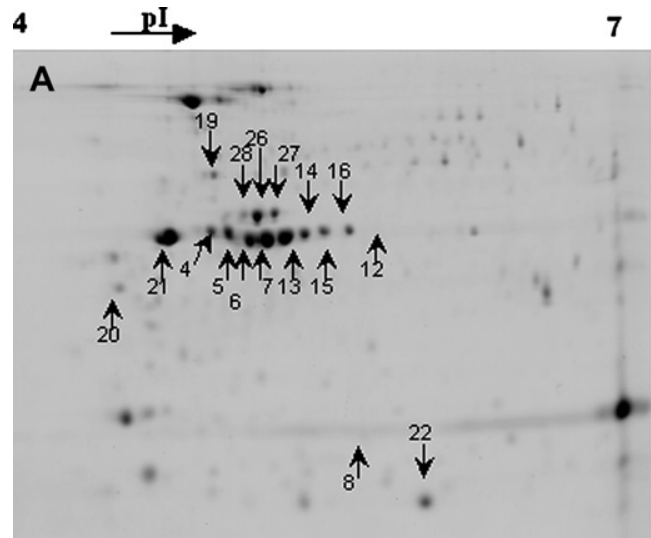

Wild (G. Soja)

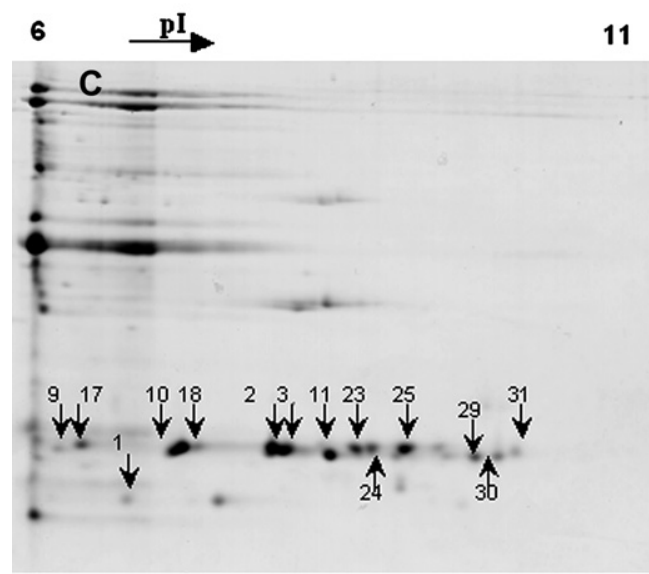

Wild (G. Soja)

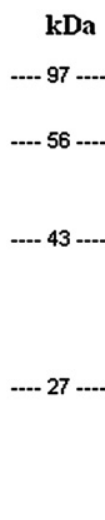

kDa

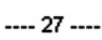

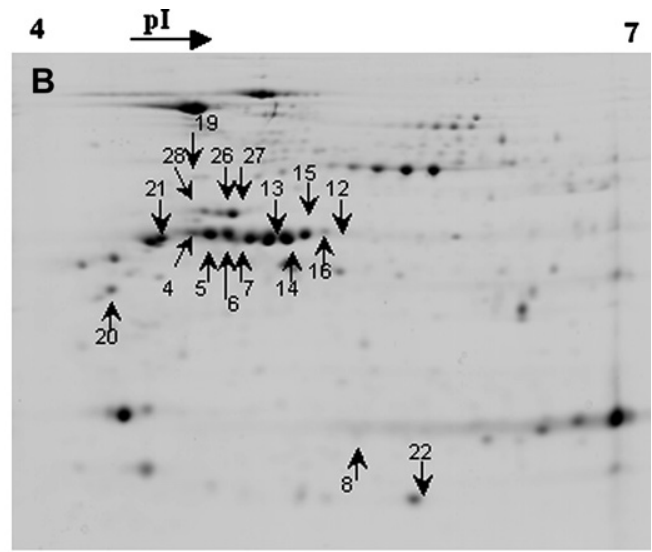

Landrace (G. max)

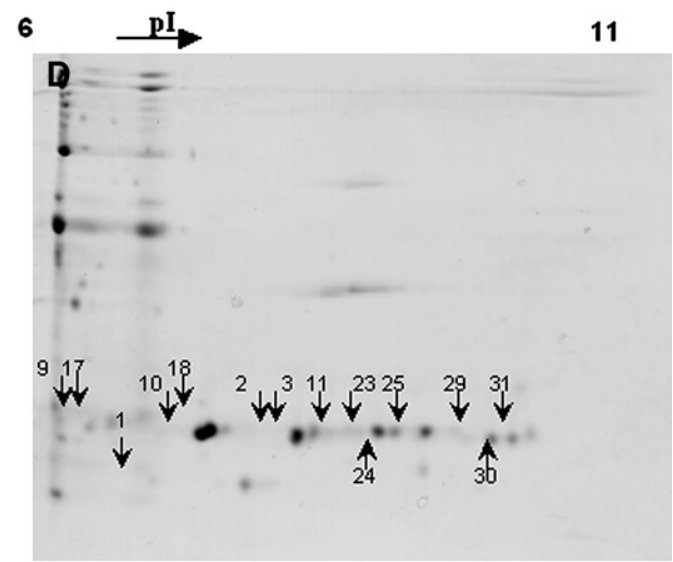

Landrace (G. max)

Fig. 1. Proteomic comparison of the glycinin proteins of wild, G. soja PI 407282 (A, C), and landrace, G. max PI 594777 (B, D). The first dimension was run using a pH gradient from 4.0-7.0 and 6.0-11.0. The second dimension was a 12\% SDS-PAGE. Gels were stained with colloidal Coomassie Blue stain G-250. Arrows indicate the glycinin protein spots that were analyzed.

8600 Variable Mode Imager (Molecular Dynamics/Amersham-Pharmacia Biotech, Sunnyvale, CA). Biology WorkBench (http://workbench.sdsc.edu/) was used for DNA sequence comparison.

\section{Results and discussion}

\subsection{Proteomic variation of glycinin subunits in 16 soybean genotypes}

In this study, we have chosen four each of wild soybean, landraces, ancestors, and modern soybean genotypes to examine proteomic and genomic variations of glycinin subunits in the seed. In order to achieve better resolution of these protein spots, we used two $\mathrm{pH}$ ranges, $4.0-7.0$ and $6.0-11.0$ in the first dimension of 2D-PAGE analysis and characterized acidic and basic chains of glycinin subunits, G1, G2, G3, G4 and G5 (Fig. 1A-D). The variation of glycinin polypeptides among group I (G1, G2, and G3) and group II (G4 and G5) glycinin subunits is discussed in detail below. Fig. 1 includes a representative $\mathrm{pH}$ 4-7 and 6-11 gel from one wild (PI407282) and one landrace (PI594777) seed sample. All separated proteins are indicated by arrows. The origin, cultivar types, maturity group, strain designation and groupings of the experimental genotypes are listed in Table 1 .

\subsection{Variation of glycinin group I subunits}

Group I consists of G1, G2 and G3 glycinin subunits. We observed remarkable variation in the number of protein spots of G1 subunit among the 16 genotypes tested. One wild (PI407027) and one landrace (PI59845) genotype showed only one basic polypeptide (spot 2). Two wild (PI366120, 407282), three landrace (PI423954, PI89138, 594777), three modern (PI536635, PI525453, PI513382), and all four ancestral (PI548445, PI548298, PI548318, PI548362) genotypes showed two basic polypeptides of G1 (spots 2 and 3). One wild (PI393551) and one modern (PI533655) genotype showed the presence of three spots of G1 (spots 1, 2 and 3). However, acidic polypeptide (A1a) of G1 (15-20 kDa) was not observed in this investigation because of its low abundance and low molecular weight [26,30]. Table 2 shows a list of all proteins identified both in wild and cultivated genotypes using MALDI-TOF-MS and LC/MS/MS analysis. We have 
Table 2

Proteins identified by MALDI-TOF-MS/LC-MS/MS in wild and cultivated genotypes

\begin{tabular}{|c|c|c|c|c|c|c|c|c|}
\hline $\begin{array}{l}\text { Spot } \\
\text { ID }\end{array}$ & Theoretical $\mathrm{p} I / M_{\mathrm{r}}$ & Protein identity & $\begin{array}{l}\text { Peptides } \\
\text { matched }\end{array}$ & $\begin{array}{l}\text { Sequence } \\
\text { coverage }(\%)\end{array}$ & $\begin{array}{l}\text { MOWSE } \\
\text { score }\end{array}$ & $\begin{array}{l}\text { Expect } \\
\text { value }\end{array}$ & Accession no. & ID method \\
\hline 1 & $5.89 / 56134$ & Glycinin G1/A1aBx subunit & 4 & 9 & 254 & & P04776 & LC/MS/MS \\
\hline 2 & $5.89 / 56299$ & Glycinin G1/A1aBx subunit & 7 & 15 & 145 & & CAA33215 & LC/MS/MS \\
\hline 3 & $5.89 / 55672$ & Glycinin G1/A1aBx subunit & 5 & 10 & 157 & & CAA33215 & $\mathrm{LC} / \mathrm{MS} / \mathrm{MS}$ \\
\hline 4 & $5.46 / 54961$ & Glycinin G2/A2B1 precursor & 9 & 14 & 74 & $6.70 \mathrm{E}-03$ & P04405 & MALDI-TOF \\
\hline 5 & $5.46 / 54961$ & Glycinin G2/A2B1 precursor & 12 & 21 & 104 & $6.10 \mathrm{E}-06$ & P04405 & MALDI-TOF \\
\hline 6 & $5.46 / 54961$ & Glycinin G2/A2B1 precursor & 9 & 19 & 91 & $1.20 \mathrm{E}-04$ & P04405 & MALDI-TOF \\
\hline 7 & $5.46 / 54961$ & Glycinin G2/A2B1 precursor & 8 & 15 & 71 & $1.30 \mathrm{E}-02$ & P04405 & MALDI-TOF \\
\hline 8 & $5.46 / 54961$ & Glycinin G2/A2B1 precursor & 3 & 9 & 177 & & P04405 & LC/MS/MS \\
\hline 9 & $5.46 / 54961$ & Glycinin G2/A2B1 precursor & 9 & 14 & 316 & & P04405 & $\mathrm{LC} / \mathrm{MS} / \mathrm{MS}$ \\
\hline 10 & $5.78 / 54047$ & Glycinin G2/A2B1 precursor & 6 & 37 & 67 & $3.20 \mathrm{E}-02$ & AAA33963 & MALDI-TOF \\
\hline 11 & $5.78 / 54047$ & Glycinin G2/A2B1 subunit & 5 & 22 & 55 & 0.64 & AAA33963 & MALDI-TOF \\
\hline 12 & $5.78 / 54047$ & Glycinin subunit G3/A1ab1B & 9 & 18 & 96 & $4.20 \mathrm{E}-05$ & 1FXZA & MALDI-TOF \\
\hline 13 & $5.78 / 54047$ & Glycinin subunit G3/A1ab1B & 8 & 19 & 72 & $1.00 \mathrm{E}-02$ & 1FXZA & MALDI-TOF \\
\hline 14 & $5.78 / 54047$ & Glycinin subunit G3/A1ab1B & 8 & 18 & 70 & $1.40 \mathrm{E}-02$ & 1FXZA & MALDI-TOF \\
\hline 15 & $5.78 / 54047$ & Glycinin subunit G3/A1ab1B & 9 & 20 & 74 & $6.40 \mathrm{E}-03$ & 1FXZA & MALDI-TOF \\
\hline 16 & $5.78 / 54047$ & Glycinin subunit G3/A1ab1B & 10 & 20 & 75 & $6.00 \mathrm{E}-03$ & 1FXZA & MALDI-TOF \\
\hline 17 & $5.78 / 54047$ & Glycinin subunit G3/A1ab1B & 9 & 18 & 116 & $3.90 \mathrm{E}-07$ & 1FXZA & MALDI-TOF \\
\hline 18 & $5.78 / 54047$ & Glycinin subunit G3/A1ab1B & 8 & 18 & 72 & $9.40 \mathrm{E}-03$ & 1FXZA & MALDI-TOF \\
\hline 19 & $5.38 / 64097$ & Glycinin G4/A5A4B3 precursor & 13 & 26 & 96 & $3.50 \mathrm{E}-05$ & AAB23212 & MALDI-TOF \\
\hline 20 & $4.46 / 24349$ & Glycinin G4/A5A4B3 precursor & 10 & 38 & 110 & $1.50 \mathrm{E}-06$ & CAB57802 & MALDI-TOF \\
\hline 21 & $5.38 / 64097$ & Glycinin G4/A5A4B3 precursor & 13 & 16 & 76 & $4.20 \mathrm{E}-03$ & AAB23212 & MALDI-TOF \\
\hline 22 & $5.38 / 64136$ & Glycinin G4/A5A4B3 precursor & 6 & 8 & 166 & & AAB23212 & $\mathrm{LC} / \mathrm{MS} / \mathrm{MS}$ \\
\hline 23 & $5.38 / 64136$ & Glycinin G4/A5A4B3 precursor & 14 & 14 & 413 & & AAB23212 & $\mathrm{LC} / \mathrm{MS} / \mathrm{MS}$ \\
\hline 24 & $5.29 / 64005$ & Glycinin G4/A5A4B3 precursor & 10 & 21 & 111 & $2.7 \mathrm{E}-06$ & P02858 & MALDI-TOF \\
\hline 25 & $5.29 / 64005$ & Glycinin G4/A5A4B3 precursor & 8 & 19 & 80 & $3.3 \mathrm{E}-03$ & P02858 & MALDI-TOF \\
\hline 26 & $5.46 / 55850$ & Glycinin G5/A3B4 subunit & 12 & 22 & 110 & $1.50 \mathrm{E}-06$ & 1OD5A & MALDI-TOF \\
\hline 27 & $5.46 / 55850$ & Glycinin G5/A3B4 subunit & 10 & 21 & 86 & $3.70 \mathrm{E}-04$ & 1OD5A & MALDI-TOF \\
\hline 28 & $5.46 / 55850$ & Glycinin G5/A3B4 subunit & 11 & 18 & 76 & $4.30 \mathrm{E}-03$ & 1OD5A & MALDI-TOF \\
\hline 29 & $5.79 / 27447$ & Glycinin G5/A3B4 subunit & 7 & 30 & 65 & $5.00 \mathrm{E}-02$ & $1303273 \mathrm{~A}$ & MALDI-TOF \\
\hline 30 & $5.79 / 27447$ & Glycinin G5/A3B4 subunit & 8 & 36 & 69 & $4.70 \mathrm{E}-02$ & $1303273 \mathrm{~A}$ & MALDI-TOF \\
\hline 31 & $5.79 / 27447$ & Glycinin G5/A3B4 subunit & 7 & 33 & 89 & & $1303273 \mathrm{~A}$ & LC/MS/MS \\
\hline
\end{tabular}

characterized the glycinin subunits and identified considerable variation of G1 basic polypeptides between wild and cultivated genotypes. There was also significant variation between landraces, ancestor and modern genotypes (Table 3). Similar variation in glycinin composition was reported by Mori et al. [20] with Japanese soybean cultivars of Tsura-no-ko and Raiden. Conversely, no variation in terms of the number of protein spots within the ancestral genotypes was observed.

In all genotypes, we observed glycinin G2 /A2B1a subunits, which showed a total of eight protein spots (nos. 4-11) of acidic and basic polypeptides with different distribution patterns (Fig. 1; Table 3). Three wild (PI393551, PI407027, PI407282), three landraces (PI423954, PI89138, PI594777), two ancestors (PI548445, PI548318), and two modern (PI525453, PI513382) genotypes showed four abundant acidic polypeptides (spots $4-7$ ) with strong protein intensity and the rest of the genotypes showed one additional acidic polypeptide (no. 8) with low protein intensity (Fig. 1; Table 3). Due to the low intensity, spot 8 was identified using LC/MS/ MS. All these acidic polypeptides mentioned above were identified as the A2 chain of the G2 subunit. We observed only minor variations in the intensity and number of protein spots of basic G2 polypeptides among these genotypes. All landrace, ancestor, and modern genotypes showed two polypeptides (spots 9 and 10) with no variation in the number of protein spots, whereas the wild genotypes showed major variation in the number of protein spots (Fig. 1). For example, of the four wild genotypes tested, one genotype (PI407027), two genotypes (PI366120, PI393551) and the remaining one genotype (PI407282) showed one (no. 10), two (nos. 9, 10) and three (nos. 9, 10,11) protein spots, respectively. Spot 11 resolved with high intensity (Fig. 1C; Table 2) in 2D-PAGE, but it was identified with a non-significant MOWSE score. The low MOWSE scores for individual subunits that are present in some spots is suggested to be the result of database entries consisting of intact proteins containing several subunits. One possibility to resolve this issue would be to create a dedicated database that includes entries for individual subunits. Spot 11 includes only basic polypeptides and has low molecular weight $\left(M_{\mathrm{r}}\right)$ and hence the sequence coverage is not sufficient to give a significant MOWSE score. The basic polypeptides (nos. 9-11) were identified as the B1a chain of G2. Variation in the number of G2 polypeptides among soybean cultivars has been reported previously $[9,18]$. The variation in the distribution of protein spots with different isoelectric points ( $\mathrm{p} I$ ) and the same $M_{\mathrm{r}}$ is most likely due to post-translational modifications [18].

In our study, both acidic and basic polypeptides of G3/ A1ab1B glycinin resolved into a total of seven spots (nos. 12-18), which showed a major variation among different 


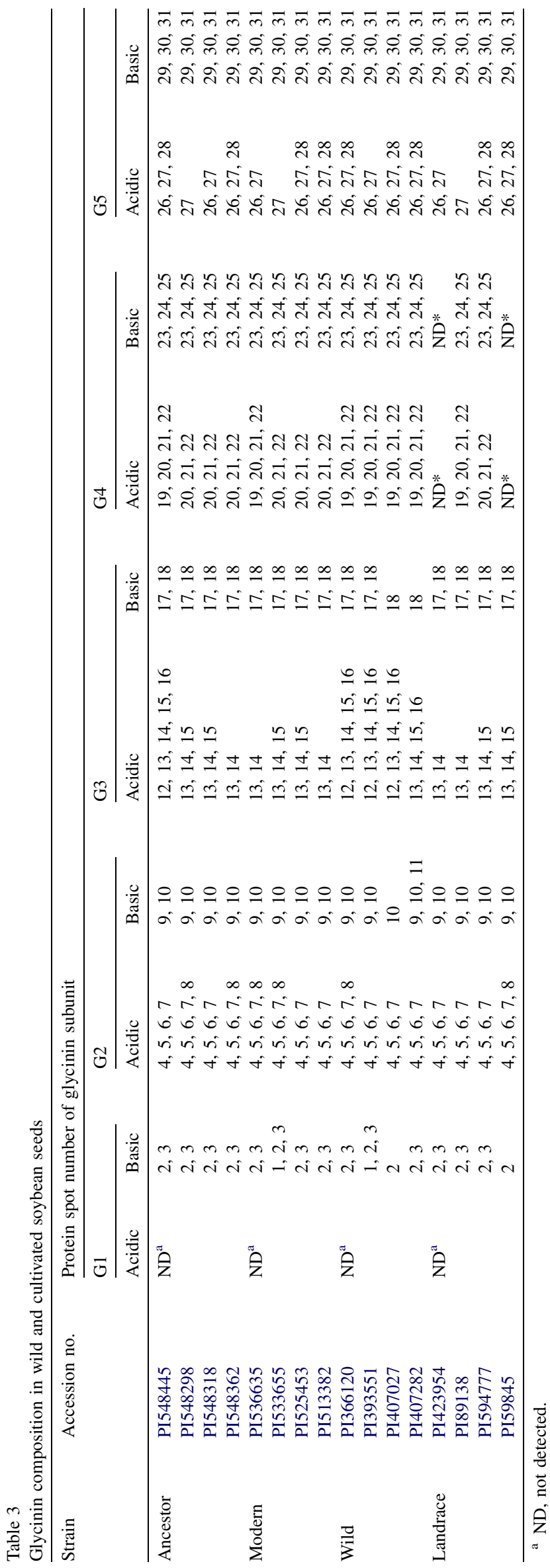

genotypes (Fig. 1A-D). Of these, spots 12-16 were identified as A1a (acidic) and spots 17 and 18 were identified as B1b (basic) components of G3 (Fig. 1). Three wild genotypes (PI366120, PI393551, and PI407027) and one ancestral genotype (PI548445) showed five acidic protein spots (nos. 12-16) and one wild genotype (PI407282) showed only four spots, lacking spot 16 (Fig. 1A,C). Two landrace genotypes (PI594777, PI59845), modern cultivars (PI536635, PI525453), and ancestors (PI548298, PI548318) showed the presence of three spots (nos. 13-15). The remaining two landraces (PI423954, PI89138), two modern genotypes (PI536635, PI513382) and one ancestral genotype (PI548362) showed two spots (nos. 13, 14) without spot 15 (Table 3). Variation in glycinin subunits was also detected in broad bean seeds [37]. These multiple forms of variation could be in part due to post-translational modification. Little variation was observed in the basic (B1b) components of G3 that showed two spots (nos. 17, 18) in most of the genotypes, except two wild genotypes (PI407027, PI407282), which were lacking spot 17 (Fig. 1C; Tables 2 and 3).

In our investigation, G1, G2 and G3 subunits of glycinin showed heterogeneity in composition and variation in terms of the number of electrophoretic isoforms between the four groups of soybean genotypes. The subunit composition of glycinin among soybean cultivars has been investigated by Harada [10] and Kitamura et al. [13]. They reported that glycinin is heterogeneous and variations in glycinin subunits occur in soybean seeds. Our 2D-PAGE analysis showed differences in the number of the acidic and basic subunits among 16 genotypes (Fig. 1A-D; Table 3). Similar variation of glycinin subunits was observed in 18 cultivars of soybean representing Japanese, US, Korean, and Chinese germplasm sources by one-dimensional gel electrophoresis [21]. The observed differences in $M_{\mathrm{r}}$ and/or $\mathrm{p} I$ could be due to proteolysis, post-translational modification, the result of alternate splicing from the same gene, and products of a multigene family or protein precursor.

\subsection{Variation of group II glycinin subunits}

Glycinin group II includes G4 (A5A4B3) and G5 (A3B4) subunits. The G4 subunit showed four acidic polypeptides (spots 19-22) by 2-D PAGE analysis (Fig. 1). Among the 16 genotypes, four wild, one landrace (PI89138), one ancestor (PI548445), and one modern cultivar (PI536635), showed the above four acidic spots with strong intensity (Fig. 1). On the other hand, the one remaining landrace (PI594777), three ancestral genotypes (PI548298, PI548318, PI548362) and three modern genotypes (PI533655, PI525453, PI513382) showed only three acidic polypeptides (nos. 20-22). There was no variation among the wild genotypes, but the other three groups (landraces, ancestors, and modern cultivars) showed a wide variation in terms of the number of protein spots between the groups and also within groups (Table 3 ).

A total of three basic polypeptides (nos. 23-25) of the G4 subunit were observed in most of the genotypes (four wild, two landraces, four ancestor and four modern). Interestingly, 
two landraces (PI 423954 and PI59845) did not have any acidic or basic polypeptides of the G4 subunit (Fig. 1; Table 3). Based on Southern blot analysis, the sequences for the G4 subunit exist in the two cultivated genotypes (Fig. 2). The absence of G4 subunit polypeptides could be due to a pseudogene, a point mutation, or an undetectable level of expression. The absence of G4 subunit due to a point mutation has been reported in soybean cv. Raiden [25,34]. Recently, Yu et al. [39] reported that the absence of the A4 peptide in the G4 glycinin subunit of the Japanese soybean cv. Enrei was caused by a point mutation. The absence of both acidic and basic G4 subunits was also observed in soybean cultivar Suzuyutaka [21,40]. Murphy et al. [22] reported that the absence of the G4 subunit results in the production of superior tofu. Based on our 2DPAGE results, two genotypes (PI 423954 and PI59845) that showed null G4 subunits might be a source for superior tofu production.

Our study revealed a major variation in acidic polypeptides but not in the basic polypeptides of the G5 subunit (Table 3). The G5 polypeptide showed three acidic polypeptides (nos. 26-28) that were classified as the A3 component of G5 and three basic polypeptides (nos. 29-31) that were classified as the B4 component (Fig. 1C,D; Table 3). Three acidic polypeptides (nos. 26-28) were present in three wild (PI366120, PI407027, PI407282), two landraces (PI594777, PI59845), two ancestors (PI548445, PI548362), and two modern (PI525453, PI513382) genotypes. One of each wild (PI393551), landrace (PI536635), and ancestral (PI548318) genotypes showed only two acidic spots (nos. 26 and 27). The remaining genotypes one ancestor (PI548298), one landrace (PI89138)
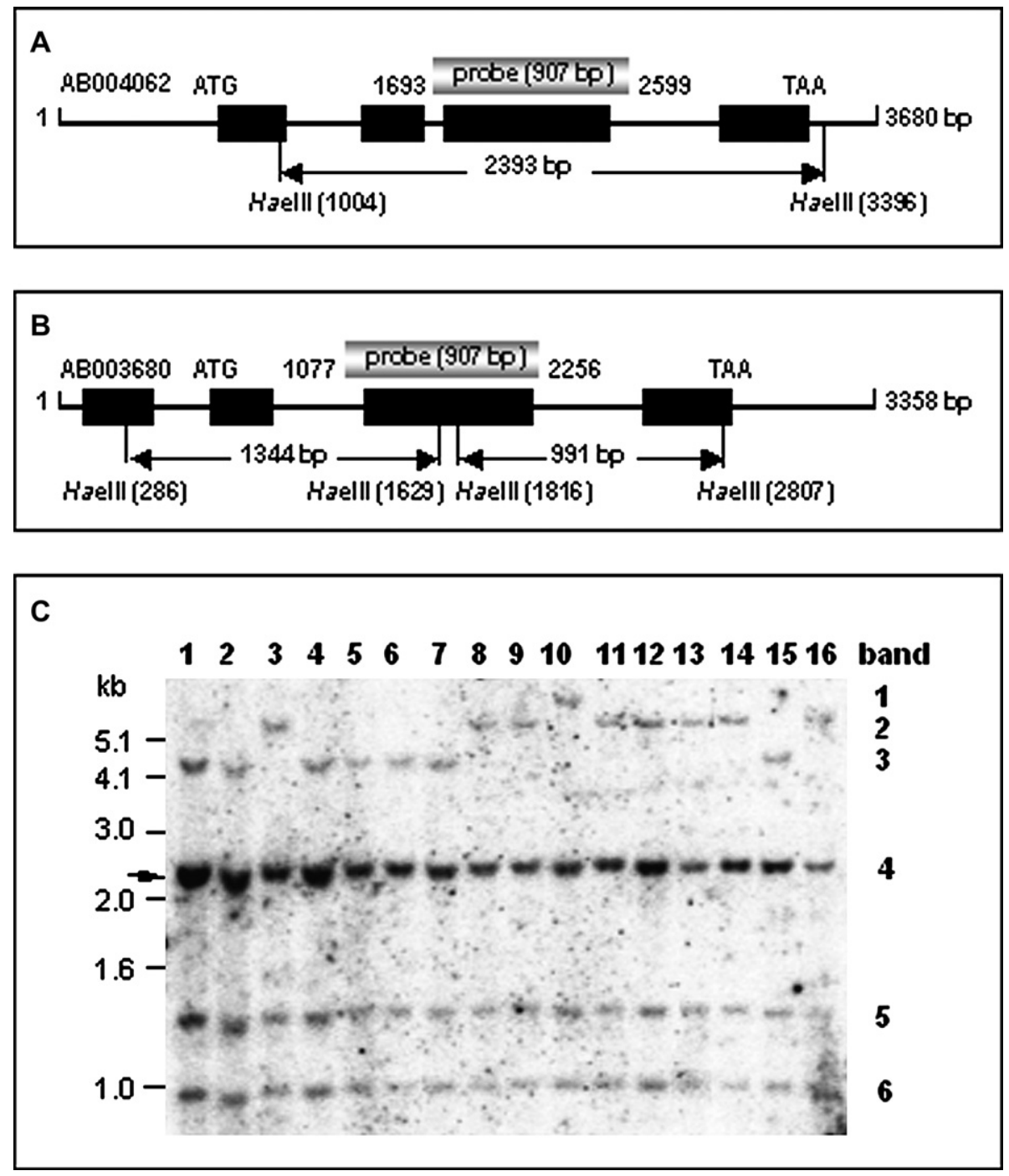

Fig. 2. Southern blot analyses of soybean glycinin genes in 16 different soybean genotypes. (A) Map of relevant restriction enzyme sites and the location of the probe within the glycinin A5A4B3 subunit (GenBank accession no. AB004062). The glycinin A5A4B3 gene consists of four exons (filled boxes). The 907-bp probe spans the third exon in the glycinin A5A4B3 gene. (B) Map of relevant restriction enzyme sites and the location of the probe within the glycinin A3B4 subunit (accession no. AB003680). The glycinin A3B4 gene consists of four exons (filled boxes). The 907-bp probe spans the third exon in glycinin A3B4 gene. (C) Soybean genomic DNA ( $2.5 \mu \mathrm{g})$ was digested with HaeIII restriction enzyme. The digested DNA was then separated on a $0.8 \%$ agarose gel, and blotted onto a nylon membrane. The blot was probed with the ${ }^{32} \mathrm{P}$-labeled 907-bp PCR product of the A5A4B3 subunit and washed under medium stringency conditions. The six band sizes detected are labeled 1-6 on the right side of the figure. The arrow indicates the glycinin A5A4B3 gene. 
Table 4

DNA band patterns for glycinin in wild and cultivated soybean genotypes

\begin{tabular}{|c|c|c|c|c|c|c|c|c|c|}
\hline \multirow[t]{2}{*}{ Lane } & \multirow[t]{2}{*}{ Subgroup } & \multirow[t]{2}{*}{ Strain } & \multicolumn{5}{|c|}{ Band patterns for HaeIII-digested DNA ${ }^{\mathrm{a}}$} & \multirow[b]{2}{*}{$u$} & \multirow{2}{*}{$\begin{array}{l}\text { Overall type } \\
\text { of band patterns }\end{array}$} \\
\hline & & & 1 & 2 & 3 & 4 & 5 & & \\
\hline 1 & \multirow[t]{4}{*}{ Ancestor } & PI 548298 & - & - & + & + & + & + & A \\
\hline 2 & & PI 548445 & - & - & + & + & + & + & A \\
\hline 3 & & PI 548318 & - & + & - & + & + & + & $\mathrm{B}$ \\
\hline 4 & & PI 548362 & - & - & + & + & + & + & A \\
\hline 5 & \multirow[t]{4}{*}{ Modern } & PI 533655 & - & - & + & + & + & + & A \\
\hline 6 & & PI 525453 & - & - & + & + & + & + & A \\
\hline 7 & & PI 513382 & - & - & + & + & + & + & A \\
\hline 8 & & PI 536635 & - & + & - & + & + & + & B \\
\hline 9 & \multirow[t]{4}{*}{ Wild } & PI 366120 & - & + & - & + & + & + & B \\
\hline 10 & & PI 393551 & + & - & - & + & + & + & $\mathrm{C}$ \\
\hline 11 & & PI 407027 & - & + & - & + & + & + & B \\
\hline 12 & & PI 407282 & - & + & - & + & + & + & B \\
\hline 13 & \multirow[t]{4}{*}{ Landrace } & PI 423954 & - & + & - & + & + & + & B \\
\hline 14 & & PI 89138 & - & + & - & + & + & + & B \\
\hline 15 & & PI 594777 & - & - & + & + & + & + & A \\
\hline 16 & & PI 59845 & - & + & - & + & + & + & B \\
\hline
\end{tabular}

a Presence and absence of a band is indicated by "+" and "-". Each number indicates a different band with different molecular weight in Fig. 1C.

and one modern (PI533665), genotype exhibited one acidic spot (no. 27). Fukazawa [8] reported similar variation of the glycinin G5 subunit between cultivated and wild genotypes. Similarly, Koshiyama [15] reported variation in glycinin subunits among several soybean cultivars. Our overall study showed considerable variation of acidic polypeptides between wild and cultivated genotypes. In contrast, variation of basic polypeptides was not observed either between or within the four groups of genotypes examined in the current study.

\subsection{Genetic polymorphisms of glycinin genes}

Southern blot analysis was conducted to determine the genomic characteristics of glycinin subunits and the genes coding for these subunits in the 16 genotypes. The 907-bp DNA fragment of Gy4 (A5A4B3, GenBank accession no. AB004062) was used as a probe to hybridize to HaeIII-digested soybean genomic DNA (Fig. 2A). The third exon of Gy4 contains the most hypervariable region (HVR) of group II subunits [25]. Subunits within the same group showed high identity (higher than 90\%) whereas subunits between groups showed low identity (less than 60\%) [27].

When soybean DNA was digested with HaeIII, six different bands were detected in all 17 genotypes (Fig. 2C and Table 4). Each genotype had four different bands (one dominant with three less intense bands). The 2393-bp band was the dominant band (no. 4, indicated by an arrow in Fig. 2C), which is the Gy4 (A5A4B3) gene according to the restriction map. The 1344-bp (band 5) and 991-bp (band 6) bands are from Gy5 (A3B4) according to the restriction map (Fig. 2B,C). The bands in the 4-6 kbp size range (nos. 1-3) showed variation among the 16 genotypes. These bands are probably from the genes of group I glycinin subunits or unreported sequences that have high homology with Gy4 (A5A4B3) gene. While bands 4,5 and 6 were consistent in the 16 genotypes, bands 1,2 and 3 were variable. Band 1 was found only in PI
393551 of G. soja (lane 10 in Fig. 2C; Table 4). This result indicates that restriction site polymorphisms exist in group I subunits. Three different types (A, B and C) of banding patterns were observed in the DNA blot analyses (Table 4). A and B types of banding patterns were observed in landrace, ancestral, modern cultivars (G. max), while B and C types of banding patterns were detected in the wild soybean genotypes $(G$. soja). In previous studies genetic diversity was detected in soybean cultivars with different geographical origins $[17,31,35]$. In this study we could also identify genetic polymorphisms of glycinin using DNA blot analysis. Based on the band numbers detected, the copy numbers of glycinin genes appear to be similar in the 16 genotypes, while restriction fragment length variation exists between and within the four groups of soybean genotypes. This result also indicates the high degree of conservation of genes encoding glycinin, which might be due to the limited genetic diversity in the parental soybean sources.

\section{Conclusion}

The results from this current study indicate that natural variation of glycinin polypeptides occurs in different groups of soybean genotypes. Our proteomic data indicated that there are major variations of glycinin subunits between wild and cultivated genotypes rather than within the same groups. In addition, one of the soybean genotypes showed the absence of the G4 glycinin subunit. On the other hand, Southern hybridizations showed that all the soybean genotypes examined have the G4 glycinin genes present. Genetic variation was observed only in group I genes (G1, G2 and G3), not in group II genes (G4 and G5). We observed major variation in the DNA banding patterns of group I genes (G1, G2, and G3) between and within the same genotypes. This is the first report of the application of proteomics and genomics to identify natural variation of glycinin subunits in 16 soybean genotypes that 
should be useful in the improvement of soybean protein composition and quality.

\section{Acknowledgments}

The authors thank Dr Jeannine Rowland and Dr Dilip. Lakshman for their critical review of this manuscript. Funding for this research was provided by ARS project 1275-21000156-00D.

\section{References}

[1] M.M. Bradford, A rapid and sensitive method for the quantitation of microgram quantities of protein utilizing the principle of protein dye binding, Anal. Biochem. 72 (1976) 248-254.

[2] J.W. Burton, Breeding soybean cultivars for increased protein percentage, in: A.J. Pascal (Ed.), Proc. World Soybean Research Conf. IV, Association Argentina de la Soja, Buenos Aires, 1989, pp. 1079-1089.

[3] T.E. Carter Jr., R.L. Nelson, C. Sneller, Z. Cui, Genetic diversity in soybean, in: H.R. Boerma, J.E. Specht (Eds.), Soybean Monograph, third ed. American Society of Agronomy, Madison, WI, 2004, pp. 303-416.

[4] T.J. Cho, C.S. Davies, N.C. Nielsen, Inheritance and organization of glycinin genes in soybean, Plant Cell 1 (1989) 329-337.

[5] Z. Cui, T.E. Carter, J.W. Burton, R. Wells, Phenotypic diversity of modern Chinese and North American soybean cultivars, Crop Sci. 41 (2001) 1954-1967.

[6] C.D. Dickinson, E.H.A. Hussein, N.C. Nielsen, Role of post-translational cleavage in glycinin assembly, Plant Cell 1 (1989) 459-469.

[7] D. Fukushima, Structures of plant storage proteins and their functions, Food Rev. Int. 7 (1991) 353-381.

[8] D. Fukushima, Recent progress of soybean protein foods: chemistry, technology, and nutrition, Food Rev. Int. 7 (1991) 323-351.

[9] J.D. Griffin, R.G. Palmer, Variability of 13 isozymes loci in the USDA soybean germplasm collections, Crop Sci. 35 (1995) 897-904.

[10] J.J. Harada, S.J. Barker, R.B. Goldberg, Soybean $\beta$-conglycinin genes are clustered in several DNA regions and are regulated by transcriptional and post-transcriptional processes, Plant Cell 1 (1989) 415-425.

[11] D.L. Hyten, Q.J. Song, Y.L. Zhu, I.Y. Choi, R.L. Nelson, J.M. Costa, J.E. Specht, R.C. Shoemaker, P.B. Cregan, Impacts of genetic bottlenecks on soybean genome diversity, Proc. Natl. Acad. Sci. U.S.A. 103 (2006) 16666-16671.

[12] S.E. Keates, T.A. Kostman, J.D. Anderson, B.A. Bailey, Altered gene expression in three plant species in response to treatment with Nep1, a fungal protein that causes necrosis, Plant Physiol. 132 (2003) 1610-1622.

[13] K. Kitamura, Y. Toyokawa, K. Harada, Polymorphism of glycinin in soybean seeds, Phytochemistry 19 (1980) 1841-1843.

[14] M. Kito, T. Moriyama, Y. Kimura, H. Kambara, Changes in plasma lipid levels in young healthy volunteers by adding an extruder-cooked soy protein to conventional meals, Biosci. Biotechnol. Biochem. 57 (1993) 354-355.

[15] I. Koshiyama, Storage proteins of soybean, in: W. Gottschalk, H.P. Müller (Eds.), Seed Proteins: Biochemistry, Genetics, Nutritive Value, Kluwer Academic Publishers, The Hague, The Netherlands, 1983, pp. 427-450.

[16] U.K. Laemmli, Cleavage of structural proteins during the assembly of the head of bacteriophage T4, Nature 227 (1970) 680-685.

[17] L.L. Lorenzen, S. Boutin, N. Young, J.E. Specht, R.C. Shoemaker, Soybean pedigree analysis using map-based molecular markers: I. Tracking RFLP markers in cultivars, Crop Sci. 35 (1995) 1326-1336.

[18] P.J. Maughan, M.A. Saghai-Maroof, G.R. Buss, G.M. Huestis, Amplified fragment length polymorphism (AFLP) in soybeans: species diversity, inheritance, and near-isogenic line analysis, Theor. Appl. Genet. 93 (1996) 392-401.
[19] B.P. Mooney, J.J. Thelen, High-throughput peptide mass fingerprinting of soybean seed proteins: automated workflow and utility of UniGene expressed sequence tag databases for protein identification, Phytochemistry 65 (2004) 1733-1744.

[20] T. Mori, S. Utsumi, Purification and properties of storage proteins of broad bean, Agric. Biol. Chem. 43 (1979) 577-583.

[21] T. Mori, S. Utsumi, H. Inhaba, K. Kitamura, K. Harada, Differences in subunit composition of glycinin among soybean cultivars, J. Agric. Food Chem. 29 (1981) 20-23.

[22] P. Murphy, H. Chen, C. Hauck, L. Wilson, Soybean protein composition and tofu quality, Food Technol. 51 (1997) 86-88.

[23] S. Natarajan, C. Xu, T.J. Caperna, W.M. Garrett, Comparison of protein solubilization methods suitable for proteomic analysis of soybean seed proteins, Anal. Biochem. 342 (2005) 214-220.

[24] S.J. Newsholme, B.F. Maleeft, S. Steiner, N.L. Anderson, L.W. Schwart, Two-dimensional electrophoresis of liver proteins: characterization of a drug-induced hepatomegaly in rats, Anal. Biochem. 21 (2000) 21222128.

[25] N.C. Nielsen, C.D. Dickinson, T.J. Cho, V.H. Thanh, B.J. Scallon, R.L. Fischer, T.L. Sims, G.N. Drews, R.B. Goldberg, Characterization of the glycinin gene family in soybean, Plant Cell 1 (1989) $313-328$.

[26] D.N. Perkins, D.J.C. Pappin, D.M. Creasy, J.S. Cottrell, Probability based protein identification by searching sequence databases using mass spectrometry data, Electrophoresis 20 (1999) 3551-3567.

[27] K. Prak, K. Nakatani, T. Katsube, M. Adachi, N. Maruyama, S. Utsumi, Structure-function relationships of soybean proglycinins at subunit levels, J. Agric. Food Chem. 53 (2005) 3650-3657.

[28] J.M.S. Renkema, J.H.M. Knabben, T. Vliet, Gel formation by beta-conglycinin and glycinin and their mixtures, Food Hydrocolloids 15 (2001) 407-414.

[29] K. Saio, M. Kamiya, T. Watanabe, Food processing characteristics of soybean $11 \mathrm{~S}$ and $7 \mathrm{~S}$ proteins, Part I. Effect of difference of protein components among soybean varieties on formation of tofu-gel, Agric. Biol. Chem. 33 (1969) 1304-1308.

[30] T.L. Sims, R.B. Goldsberg, The glycinin Gy1 gene from soybean, Nucleic Acids Res. 17 (1989) 4386.

[31] H.T. Skorupska, R.C. Shoemaker, A. Warner, E.R. Shipe, W.C. Bridges, Restriction fragment length polymorphism in soybean germplasm of the southern USA, Crop Sci. 33 (1993) 1169-1176.

[32] P.E. Staswick, M.A. Hermodson, N.C. Nielsen, Identification of the cystines which link the acidic and basic components of the glycinin subunits, J. Biol. Chem. 259 (1984) 13431-13435.

[33] P.E. Staswick, M.A. Hermodson, N.C. Nielsen, Identification of the acidic and basic subunit complexes of glycinin, J. Biol. Chem. 256 (1981) 8752-8755.

[34] P.E. Staswick, N.C. Nielsen, Characterization of soybean cultivars lacking certain glycinin subunits, Arch. Biochem. Biophys. 223 (1983) 1-8.

[35] J.A. Thompson, R.L. Nelson, Core set of primers to evaluate genetic diversity in soybean, Crop Sci. 38 (1998) 1356-1362.

[36] S. Utsumi, Plant food protein engineering, in: J.E. Kinsella (Ed.), Advances in Food and Nutrition Research 36, Academic Press, San Diego, CA, 1992, pp. 89-208.

[37] S. Utsumi, H. Inaba, T. Mori, Formation of pseudo and hybrid 11S globulins from subunits of soybean and broad bean 11S globulins, Agric. Biol. Chem. 44 (1980) 1891-1896.

[38] S. Utsumi, Y. Matsumura, T. Mori, Structure-function relationships of soy proteins, in: S. Damodaran, A. Paraf (Eds.), Food Proteins and their Applications, Marcel Dekker, New York, 1997, pp. 257-291.

[39] K. Yu, V. Poysa, M. Haffner, B. Zhang, L. Woodrow, Absence of the A4peptide in the G4 glycinin subunit of soybean cultivar Enrei is caused by a point mutation in the Gy4 gene, Genet. Mol. Biol. 28 (2005) 440-443.

[40] G.Y. Zhang, Y. Hayashi, S. Matsumoto, Y. Matsumura, T. Mori, Molecular species of glycinin in some soybean cultivars, Phytochemistry 60 (2002) 675-681. 